\title{
ZARZĄDZANIE MOBILNOŚCIĄ MIEJSKĄ - INSTRUMENTY I PODSTAWOWE ETAPY WDRAŻANIA ZRÓWNOWAŻONYCH PLANÓW ZARZĄDZANIA (SUMP)
}

\author{
Bartłomiej Osyra \\ Politechnika Częstochowska \\ Wydział Zarządzania
}

\begin{abstract}
Streszczenie: Artykuł poświęcony jest wybranym zagadnieniom związanym z problematyką mobilności miejskiej. Wychodząc od problemów, jakie wiążą się ze wzrostem mobilności, zasygnalizowano cele i istotę rozwoju koncepcji zarządzania mobilnością. Obszarem zainteresowania są z kolei wyłącznie tereny miejskie, z uwagi na szczególną koncentrację negatywnych zjawisk związanych ze wzrostem mobilności, jakie obserwuje się właśnie na tych terenach. Dodatkowo w oparciu o badania literaturowe przedstawiono katalog najważniejszych instrumentów i środków, za pomocą których zarządza się mobilnością na obszarach miejskich.
\end{abstract}

Słowa kluczowe: mobilność miejska, zachowania transportowe, zrównoważone plany zarządzania mobilnością miejską, SUMP

DOI: 10.17512/znpcz.2016.2.19

\section{Wprowadzenie}

U podłoża dynamicznego rozwoju badań nad mobilnością miejską, jaki obserwujemy od II połowy XX wieku, legły narastające problemy komunikacyjne w miastach, w sposób bezpośredni przekładające się na jakość życia ich mieszkańców, a których nie udaje się już rozwiązywać dalszą rozbudową infrastruktury drogowej. Coraz większe ograniczenie infrastrukturalne spowodowane jest m.in. wzrastającą liczbą mieszkańców posiadających samochody zamieszkujących w ścisłych centrach miast.

Wpływa to również na obserwowane zmniejszenie liczby pasażerów komunikacji zbiorowej, przy jednoczesnym wzroście użytkowników komunikacji indywidualnej. Przyczyn tego stanu jest kilka - począwszy od dużego udziału starego taboru, niskiej jakości usług komunikacji miejskiej, w tym: prędkości i skomunikowania podróży, poprzez politykę niewystarczająco promującą transport zbiorowy, a skończywszy na braku silnego lobby promującego transport publiczny i ekologiczne środki podróży. Wszystko to powoduje, że Polacy przy poziomie PKB per capita będącym równowartością 20.600 USD i nie najwyższym w stosunku do reszty państw UE poziomie średnich dochodów (http://ec.europa.eu/eurostat/statistics-explained/index.php/File: Annual_net_earnings,_2014_(EUR)_YB15.png) posiadają ok. 450 samochodów osobowych na 1000 mieszkańców (w Warszawie 600), co przy średniej unijnej wynoszącej 470 jest wysokim wynikiem (Załącznik do Uchwały nr 238.XX.2015 Rady Miasta Częstochowy z dnia 30 grudnia 2015 r., poz. 481). 
Według danych Eurostatu i Komisji Europejskiej 72\% mieszkańców Unii Europejskiej zamieszkuje obszary zurbanizowane (Opracowanie Dyrekcji Generalnej ds. Polityki Wewnętrznej Komisji Europejskiej, Plan zrównoważonego transportu miejskiego, 2010, s. 15), a niemal $42 \%$ mieszka w granicach administracyjnych miast (http://ec.europa.eu/eurostat/cache/RSI/\#?vis=typologies.urb_typology oraz http://uniaeuropejska.org/eurostat-41-proc-europejczykow-mieszka-w-miastach/) - podobny trend zauważalny jest w Polsce, gdzie dane GUS wskazują, że odsetek mieszkańców miast wynosi $52,2 \%{ }^{1}$. Oczywiście na wynik pomiaru procentowego odsetka ludności zamieszkującej tereny miejskie duży wpływ ma metodologia kwalifikacji terenów jako obszarów zurbanizowanych, jednak każdy z pomiarów potwierdza obserwowany trend wzrostowy liczby osób zamieszkujących tereny miejskie w Polsce, co w sposób bezpośredni przekłada się na zwiększoną liczbę pojazdów w miastach (Pifczyk 2016).

Celem artykułu jest przedstawienie problemów wiążących się ze wzrostem mobilności. Zasygnalizowane zostaną cele oraz istota rozwoju koncepcji zarządzania mobilnością miejską. Ponadto na podstawie badań literaturowych przedstawiony zostanie katalog najważniejszych instrumentów i środków, jakimi zarządza się mobilnością na obszarach miejskich.

\section{Mobilność i problemy, jakie generuje}

Stale wzrastający odsetek ludności Polski zamieszkującej obszary zurbanizowane jest wynikiem zarówno rozszerzania się oddziaływania struktur miejskich, jak i obserwowanych w ostatnim dwudziestoleciu zmian zachowań transportowych i stylu życia Polaków, których widoczną oznaką jest m.in. zwiększenie ich mobilności. Czym jednak jest mobilność? W znaczeniu potocznym - utożsamiana jest często z aktywnością, energią i zdolnością do elastycznego działania w stosunku do osób oraz możliwością przenoszenia i przesuwania w odniesieniu do rzeczy (http://sjp.pwn.pl/slowniki/mobilno\%C5\%9B\%C4\%87.html). W sferze logistyki miejskiej - mobilnością możemy określić ogół zachowań transportowych związanych z przemieszczaniem się osób na danym obszarze, jak i wszelkie działania zmierzające do osiągnięcia celu tego przemieszczania (np.: praca, nauka, rozrywka, sprawy socjalne i kulturalne), które ruch danej osoby generują (Hebel 2013, s. 32). Mobilność nieodłącznie związana jest z działalnością człowieka i jego zachowaniami transportowymi, które obejmują dwie decyzje. Pierwsza to decyzja o podjęciu podróży lub jej zaniechaniu, druga dotyczy wyboru środka transportu, czasu planowanej podróży oraz jej trasy (Szołtysek 2011, s. 145). Co ważne, na podjęcie obu decyzji istotny wpływ ma cały zestaw czynników o charakterze zarówno zewnętrznym, jak i wewnętrznym, z których najważniejsze nazwać możemy psychologiczno-społecznymi. Jest to nic innego jak oddziaływanie poglądów i opinii

\footnotetext{
${ }^{1}$ Co prawda w stosunku do spisu powszechnego z 2002 roku, odsetek ten uległ zmniejszeniu o 1,6\%, jednak wynika ono głównie z migracji ludzi z dużych ośrodków miejskich na ich przedmieścia, leżące już na terenach administracyjnie wyodrębnianych jako obszary wiejskie. Duży wpływ ma również metodologia kwalifikacji terenów jako obszary zurbanizowane, http://stat.gov.pl/cps/rde/xbcr/gus/lu_nps2011_wyniki_nsp2011_22032012.pdf, s. 6 (dostęp: 19.02.2016).
} 
kształtujących wyobrażenie jednostki o tym, jak można najefektywniej odbyć podróż. Dodatkowo na zachowania transportowe, czyli na mobilność jednostki, wpływ wywierają również czynniki ekonomiczne, a nawet ekologiczne. Czynniki te nabierają coraz większego znaczenia w miarę wzrostu świadomości społecznej na temat negatywnego oddziaływania transportu na środowisko naturalne, ale wciąż dominującym pozostaje trend charakteryzujący się postrzeganiem samocho$\mathrm{du}$, ,jako produktu umożliwiającego nie tylko swobodne poruszanie się, ale odgrywającego zarazem rolę symbolu sukcesu i stanowiącego jednocześnie widoczny dowód zamożności mieszkańców" (Low i in. 2005, s. 133). Skutkiem takiego postrzegania jest wytworzenie się specyficznej kultury samochodowej, która wpływa na popyt na samochody i sprawia, że - szczególnie w krajach wysoko rozwiniętych - stają się one niemal dobrem powszechnie dostępnym. Zjawisko to ma jednak negatywne konsekwencje. Ludzie większą wagę zaczęli przywiązywać do środka transportu oraz do całej otoczki związanej z wykorzystywaniem samochodu jako głównego środka lokomocji niż celu i efektywności podróży (Urry 2009, s. 89). Dodatkowo, jak słusznie zaznacza A. Rudnicki, „,bardzo niska efektywność wykorzystania przez samochód osobowy z natury deficytowej przestrzeni komunikacyjnej prowadzi do narastających stanów zatłoczenia motoryzacyjnego dróg" (Rudnicki 2010 , s. 58). To - w połączeniu z wciąż niskim poziomem zintegrowania i atrakcyjności komunikacji publicznej, mogącej stanowić alternatywny środek transportu w terenie miejskim - powoduje coraz powszechniejsze występowanie zjawiska kongestii komunikacyjnej, która wraz z wzrastającym poziomem zanieczyszczenia powietrza oraz malejącym poziomem ochrony akustycznej jest jedną z przyczyn obniżania się jakości życia $\mathrm{w}$ miastach ${ }^{2}$. Dodatkowym problemem jest niewdrażanie narzędzi zarządzania zachowaniami transportowymi, których głównym celem ma być niwelowanie negatywnych skutków mobilności. Wynikiem takiego zachowania jest utrzymywanie się wadliwych przepływów transportowych w kanałach logistycznych, co z kolei generuje straty ekonomiczne, ekologiczne i społeczne, co stoi w sprzeczności z zasadami zrównoważonego transportu.

Etapy rozwoju mobilności mieszkańców oraz jego negatywne efekty, przedstawiono na Rysunku 1.

Wzrost mobilności mieszkańców często wspomagany jest przez małą atrakcyjność środków transportu alternatywnych do transportu osobowego/ indywidualnego. Brak wdrożenia narzędzi zarządzania mobilnością na tym etapie przekłada się na wzrost ilości transportu indywidualnego powodujący kongestie transportowe oraz zanieczyszczenie środowiska naturalnego. To z kolei powoduje spadek jakości życia w mieście, który przekłada się na migracje i osiedlanie się ludzi na jego obrzeżach. Ta migracja powoduje niekontrolowany rozwój miast oraz rozrost infrastruktury drogowej, po wybudowaniu której proces zatacza krąg.

\footnotetext{
${ }^{2} \mathrm{Z}$ danych $\mathrm{z}$ Tom Tom Trafic Index wynika, że Warszawa jest na 9. miejscu w rankingu miast z największym współczynnikiem kongestii transportowej na świecie (dane z listopada 2014 r.) http://www.tomtom.com/pl_pl/trafficindex/\#/list.
} 


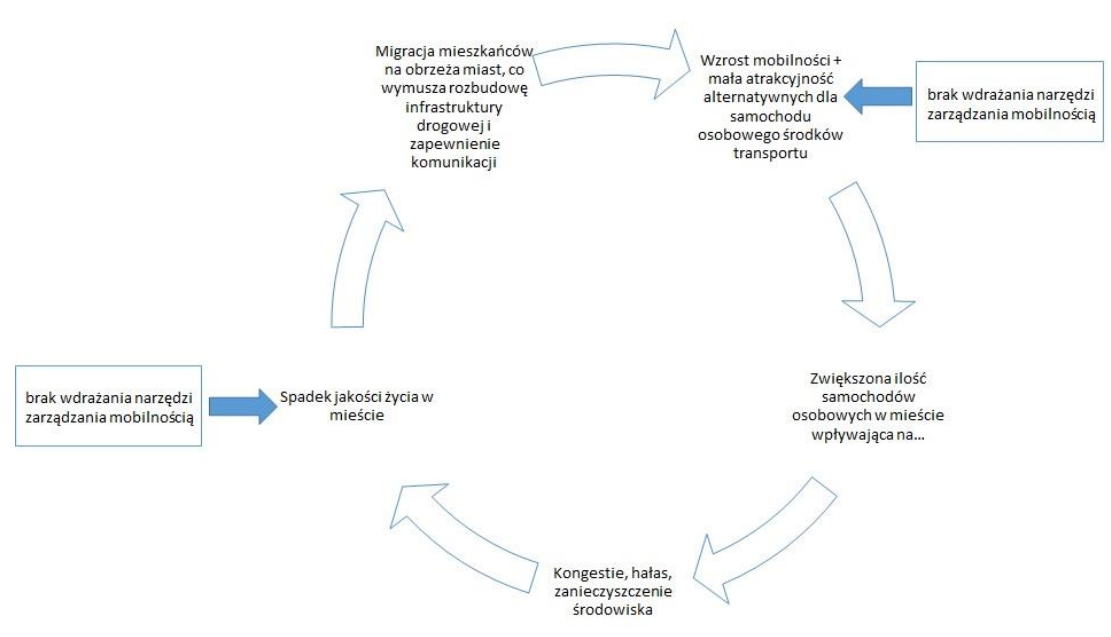

Rysunek 1. Problemy związane z brakiem zarządzania mobilnością miejską

Źródło: Opracowanie własne

\section{Zarządzanie mobilnością miejską}

By przeciwdziałać negatywnym zjawiskom związanym ze wzrostem mobilności, szczególnie w ośrodkach miejskich, zauważono konieczność podjęcia próby zarządzania zachowaniami transportowymi ludności. Odpowiedzią na to wyzwanie była, powstała w połowie lat dziewięćdziesiątych XX wieku, koncepcja zarządzania mobilnością. Zastąpiła ona strategię opartą na prognozowaniu ruchu miejskiego i dostosowywaniu do niego infrastruktury (predict and provide approach) (Nosal, Starowicz 2010, s. 2), która nie uwzględniała średnio- i długofalowych zmian zachowań komunikacyjnych, a poprzez rozbudowę infrastruktury zachęcała użytkowników do zwiększonego jej wykorzystywania (por. Suchorzewski 2009, s. 195206; Brzeziński 2014, s. 1-9). Zarządzanie mobilnością z kolei wyrosło z podejścia psychologiczno-socjologicznego, koncentrującego się na szerokim spektrum czynników wpływających na decyzję jednostki o wyborze środka transportu. Stąd też zarząazzanie mobilnością utożsamia się z zespołem działań i zachęt związanych z planowaniem, organizowaniem, koordynowaniem (kierowaniem) i kontrolowaniem przemieszczania się ludzi i towarów na obszarze miejskim, których celem jest wywieranie wpływu na postawy i zachowania komunikacyjne ludzi. W literaturze przedmiotu spotkać można również opinie, że celem tych działań i zachęt jest dosłownie „kształtowanie popytu na alternatywne środki transportu w stosunku do samochodów osobowych" (Nosal, Starowicz 2010, s. 3; Hebel 2014, s. 88). Jak jednak podkreśla K. Nosal, koncepcja zarządzania mobilnością nie dąży do całkowitego wyeliminowania podróży wykonywanych samochodem osobowym, ale troszczy się o bardziej racjonalne wykorzystanie tego środka lokomocji, jak na przykład korzystanie z samochodu w przypadku braku możliwości wyboru innego środka transportu lub wspólne użytkowanie jednego samochodu przez kilka osób w systemach carpoolingu czy carsharingu (Nosal 2009, s. 179). 
Istotą zarządzania mobilnością jest zatem wywieranie wpływu na zachowanie jednostki, by przy pozostawieniu jej swobody wyboru środka transportu zwiększyć konkurencyjność transportu proekologicznego w stosunku do pojazdów indywidualnych. Zarządzanie mobilnością miejską jest zatem częścią koncepcji zrównoważonej mobilności, która charakteryzuje się ,,podejmowaniem racjonalnego, społecznie akceptowanego, ekologicznie odpowiedzialnego, elastycznego wyboru sposobu podróżowania" (por. Chamier-Gliszczyński, Krzyżyński 2011, s. 56). Drugim ważnym elementem składającym się na istotę tej koncepcji jest taki wzrost świadomości mobilności miejskiej, by zmotoryzowani byli gotowi do rezygnacji z użycia samochodu, w przypadku gdy istnieje alternatywa odbycia zaplanowanej podróży konkurencyjnymi środkami transportu przy porównywalnej efektywności podróży. Jest to zatem nic innego jak zmiana zachowań transportowych w kierunku odpowiedzialnego korzystania z samochodu (Rudnicki, Starowicz 2007, s. 447; Nosal 2011, s. 83-84; Ciastoń-Ciulkin, Puławska 2014, s. 2750).

Wszystkie te zabiegi związane z zarządzaniem mobilnością dążą do osiągnięcia następujących celów przedstawionych w Tabeli 1 .

\section{Tabela 1. Cele zarządzania mobilnością}

\begin{tabular}{|c|}
\hline Cele zarządzania mobilnością \\
\hline $\begin{array}{c}\text { Zaspokojenie potrzeb komunikacyjnych poprzez zintegrowane i bardziej efektywne wykorzystanie } \\
\text { istniejącej infrastruktury transportowej i układu urbanistycznego. }\end{array}$ \\
\hline $\begin{array}{l}\text { Niwelowanie natężenia ruchu w układzie transportowym poprzez ograniczenie liczby i długości } \\
\text { podróży do niezbędnego minimum oraz promocję rozwiązań ograniczających zapotrzebowanie na } \\
\text { te podróże. }\end{array}$ \\
\hline $\begin{array}{l}\text { Zmniejszenie negatywnego oddziaływania na środowisko naturalne pojazdów poprzez zastosowa- } \\
\text { nie pojazdów wydajniejszych energetycznie oraz paliw ze źródeł odnawialnych. }\end{array}$ \\
\hline $\begin{array}{c}\text { Poprawa dostępności do transportu dla jak największej liczby mieszkańców poprzez poprawę } \\
\text { infrastruktury transportu publicznego, rowerowej i pieszej. }\end{array}$ \\
\hline $\begin{array}{l}\text { Zwiększenie standardu podróży środkami komunikacji publicznej oraz zachęcanie do wspólnego } \\
\text { korzystania z pojazdów osobowych. }\end{array}$ \\
\hline $\begin{array}{c}\text { Zwiększenie poziomu intermodalności różnych środków transportu w celu usprawnienia połączeń } \\
\text { między istniejącymi sieciami transportowymi (np. poprzez wdrażanie systemów Park \& Ride, } \\
\text { Bike \& Ride). }\end{array}$ \\
\hline $\begin{array}{l}\text { Zwiększenie efektywności ekonomicznej systemu transportowego przy jednoczesnym dostosowa- } \\
\text { niu do go potrzeb użytkowników. }\end{array}$ \\
\hline
\end{tabular}

Źródło: Opracowanie własne

Aby osiągnąc te cele, w ramach zarządzania mobilnością, stosuje się szereg instrumentów wpływających na mieszkańców w sferze ich zachowań transportowych.

\section{Instrumenty zarządzania mobilnością wykorzystywane na obszarach miejskich}

W toku rozwoju koncepcji zarządzania mobilnością wypracowano szereg instrumentów oddziaływania na zachowania transportowe i przyzwyczajenia mieszkańców związane z ich przemieszczaniem się na danym obszarze. Część z nich skupia się na zwiększeniu wachlarza oferty komunikacyjnej poprzez zapropono- 
wanie alternatywnych dla pojazdów samochodowych środków transportu, inne dążą do ograniczania liczby podróży, jej optymalizacji lub zastąpienia, choćby za pomocą wykorzystania technologii teleinformatycznej. Jeszcze inne, jak słusznie podkreślają niektórzy przedstawiciele nauki, dążą do swoistego przemodelowania procesu planowania przestrzennego i uwzględnienia w nim zadań związanych z zarządzaniem mobilnością nie tylko na poziomie miast, ale nawet firm działających na ich terenie (Litman 2002, s. 23; Engelskirchen 2011, s. 34-36).

Wdrożenia ww. instrumentów oraz ujęcie ich w zbiory dobrych praktyk dają podstawę do stworzenia zrębów katalogu instrumentów zarządzania mobilnością na obszarach miejskich. Oczywiście katalog ten nie jest zbiorem zamkniętym, gdyż dziedzina ta podlega ciągłemu dynamicznemu rozwojowi, którego efektem są nowe pomysły i kolejne wdrażane narzędzia wpływu na mobilność miejską. Niemniej jednak do podstawowych instrumentów zarządzania mobilnością zaliczyć możemy:

- Instrumenty planistyczne - tego typu narzędzia odnoszą się do organizowania przestrzeni funkcjonowania człowieka na określonym terenie. Mogą one wywierać wpływ na stopień zatłoczenia komunikacyjnego danych fragmentów miast, gdzie np. zauważalne jest zwiększone zjawisko kongestii komunikacyjnej, lub na sterowanie popytem na alternatywne w stosunku do samochodów środki transportu. Przykładem wdrażania tych instrumentów jest: wyłączanie części miast $\mathrm{z}$ indywidualnego ruchu samochodowego (http://www.gdansk.pl/ urzad/mobile,512,11727.html), uspokajanie ruchu poprzez wprowadzania limitów prędkości (http://edroga.pl/inzynieria-ruchu/katowice-strefa-tempo-30-juzobowiazuje-170811883) lub wizualne zawężanie pasów drogowych poprzez wyznaczanie drogi rowerowej czy poszerzanie parkingów, co przekłada się na zmniejszenie prędkości pojazdów oraz wzrost bezpieczeństwa innych uczestników ruchu drogowego. Kolejnym przykładem oddziaływania na mobilność mieszkańców poprzez instrumenty planistyczne jest projektowanie tzw. obszarów wielofunkcyjnych, gdzie zagęszczenie wielu funkcji, np. mieszkalnych, szkół, pracy, usług i kulturalnych, powoduje zmniejszenie ilości i potrzeb podróży wykonywanych samochodami (Rudnicki 2010, s. 61-62; NowakowskaGrunt, Chłąd 2015, s. 136) . $^{3}$

- Instrumenty inwestycyjne - związane są głównie z budową lub modernizacją miejskiej infrastruktury transportowej. Zarządzanie mobilnością miejską przy wykorzystaniu tego typu instrumentów wiąże się co prawda $\mathrm{z}$ dużą kosztochłonnością, jednak koszty te ponoszone są w celu zaoferowania mieszkańcom wysokiej jakości infrastruktury dla środków transportu alternatywnych wobec samochodu osobowego. I tak w ramach wykorzystywania tego narzędzia budowane są najczęściej drogi rowerowe w celu uzupełnienia ich sieci, kupowany jest nowy i ekologiczny tabor pojazdów komunikacji miejskiej, który wraz z zastosowaniem inteligentnych systemów transportowych (ITS - ang. Intelligent Transportation Systems) ma usprawnić przemieszczanie się w mieście poprzez

${ }^{3}$ Potential Transportation Demand Management Strategies, Victoria Transport Institute, Online TDM Encyclopedia, www.vtpi.org/tdm/tdm67.htm (dostęp: 19.02.2016). 
skrócenie czasu podróży. Dodatkowo modnym ostatnio przykładem wykorzystania instrumentów finansowych w celu wpływania na zachowania transportowe mieszkańców są budowy miejskich centrów przesiadkowych (Park \& Ride, Bike \& Ride), których celem jest zwiększenie intermodalności transportu.

- Instrumenty finansowe - ich wdrożenie wiąże się ze swoistą dolegliwością finansową dla użytkowników indywidualnych środków transportu, a ich podstawowym celem jest ograniczenie ich ilości. Mowa tu szczególnie o samochodach prywatnych, których koszt użytkowania w miastach ma wzrastać, przez co ich wykorzystywanie ma być mniej atrakcyjne w porównaniu z innymi środkami transportu. Najpowszechniej stosowane instrumenty tego typu to poszerzanie stref płatnego parkowania $\mathrm{w}$ centach miast, wzrost opłaty za wjazd samochodów do danego obszaru miasta (tzw. opłaty kongestyjne) wraz z ich uzależnieniem od czasu przebywania pojazdu w tej strefie (która ma na celu wymuszenie rotacji pojazdów w strefie parkowania).

- Instrumenty marketingowo-edukacyjne - za takie instrumenty uznaje się szerokie spektrum działań skierowanych do wszystkich grup użytkowników dróg i mieszkańców miast, które mają na celu zmianę zachowań komunikacyjnych poprzez promocję komunikacji publicznej i ekologicznych środków transportu miejskiego oraz edukację $\mathrm{w}$ zakresie zrównoważonego transportu i odpowiedzialnego wykorzystywania samochodu w mieście. Dodatkowo instrumenty promocyjno-edukacyjne każdorazowo stosowane są przy wdrażaniu instrumentów planistycznych, inwestycyjnych, a w szczególności administracyjnoprawnych. Ich rolę można zatem określić jako instrumenty pomocnicze, które na zasadzie synergii działań mają pomagać osiągnąć założone efekty. Przykładem najczęściej stosowanych działań marketingowo-edukacyjnych z zakresu zarządzania mobilnością miejską są np. tworzenie miejskich biur mobilności, zajmujących się dostarczaniem mieszkańcom niezbędnych informacji z zakresu skomunikowania poszczególnych rejonów miasta oraz doradztwa w tym temacie. To także miejsca przygotowania analiz na temat alternatywnych w stosunku do samochodów środków transportu w mieście (wraz z porównaniami kosztowymi i czasów podróży). To również szerokie spektrum materiałów promocyjnych i poligraficznych dystrybuowanych wśród mieszkańców, których celem jest zwiększanie świadomości społecznej na temat szkodliwości nadmiernego użytkowania indywidualnych pojazdów samochodowych i negatywnych jego skutków. Do działań informacyjno-edukacyjnych zaliczamy także cykliczne akcje i obchody np. Tygodnia Zrównoważonego Transportu lub Dnia bez Samochodu, w czasie których - szczególnie wśród dzieci i młodzieży - promowana jest idea zrównoważonego transportu miejskiego przekazywana $\mathrm{w}$ formie gier, konkursów i zabaw miejskich (Niewitała, Ochyra 2008, s. 12-16; Nosal 2014, s. 4687-4696).

- Instrumenty administracyjno-prawne - ostatnim i chyba najistotniejszym narzędziem wpływającym na rozwój mobilności miejskiej są wszelkiego rodzaju dokumenty, strategie i regulacje zarówno o zasięgu międzynarodowym, jak i te, których zasięg obejmuje terytorium jednego kraju lub jest ograniczony wyłącznie do terenu jednego miasta. Dokumenty te mogą być zaakceptowanymi i wdrożonymi 
programami działania w zakresie zarządzania mobilnością na danym obszarze, identyfikując zagrożenia związane z zachowaniami transportowymi oraz postulując wdrożenie innych instrumentów zarządzania mobilnością (por.: NowakowskaGrunt, Chłąd 2015, s. 136). Przykładem tego typu dokumentów są popularne na zachodzie Europy Plany Zrównoważonej Mobilności Miejskiej (tzw. SUMP), a w Polsce m.in.: Polityka Transportowa Państwa na lata 2006-2025 (http:// docplayer.pl/1887295-Ministerstwo-infrastruktury-polityka-transportowa-panstwana-lata-2006-2025.html), Strategia Transportu i Mobilności Gdańskiego Obszaru Metropolitalnego do roku 2030 (http://www.metropoliagdansk.pl/ upload/files/2_ Raport\%20szczeg\%C3\%B3\%C5\%82owy\%20badania\%20i\%20pomiary\%20XII \%202014.pdf) czy Wrocławska Polityka Mobilności (Załącznik do uchwały Rady Miasta Wrocławia z dnia 19 września 2013 r.).

W tym miejscu warto nieco więcej uwagi poświęcić samym Planom Zrównoważonej Mobilności Miejskiej jako tym dokumentom, które stanowią swoistą mapę drogową do wdrażania polityki zrównoważonej mobilności miejskiej oraz synergicznego wsparcia pozostałych instrumentów zarządzania tą mobilnością.

\section{Plany Zrównoważonej Mobilności Miejskiej (SUMP) i etapy ich tworzenia}

Za podstawowy dokument zarządzania mobilnością o charakterze miejskim uznawany jest Zrównoważony Plan Mobilności Miejskiej, czyli tzw. SUMP (Sustainable Urban Mobility Plan). Na wagę tego dokumentu wpływa fakt, że z założenia ma on wyznaczać lokalne kierunki zarządzania mobilnością miejską w zgodzie z polityką zrównoważonego transportu miejskiego, łącząc w całość instrumenty zarządzania mobilnością. Jest to zatem rola nie do przecenienia, która uzasadnia konieczność analizy pewnych uniwersalnych etapów tworzenia tego typu dokumentów. W tym miejscu zaznaczyć należy, że każdy wdrażany SUMP powinien odzwierciedlać lokalną specyfikę komunikacji i zachowań transportowych, niemniej jednak na podstawie wielu wdrożonych planów mobilności, w toku wymiany dobrych praktyk udało się ustalić pewien zbiór etapów wdrażania i prawidłowego funkcjonowania tego planu. Jedna z wytycznych dotyczących etapów wdrażania SUMP zawarta została w tzw. Policy Advice Notes projektu CIVITAS (Policy Advice Notes 2008) i ona jest przedmiotem dalszej analizy4.

\footnotetext{
${ }^{4} \mathrm{~W}$ Unii Europejskiej powołano szereg projektów i inicjatyw, których celem jest promocja zrównoważonego rozwoju w szczególności w kwestii wypracowania i wdrożenia projektu zintegrowanej polityki transportu w miastach. Jedną z nich jest CIVITAS, w którą na przestrzeni ostatnich 14 lat zaangażowało się ponad 200 europejskich miast. CIVITAS to inicjatywa powołana przez Komisję Europejską w październiku 2002 roku, w ramach 5 Programu Ramowego Badań i Rozwoju. Nazwa pochodzi od pierwszych liter słów: City (miasto), Vitality (witalność) i Sustainability (zrównoważony rozwój), które to określają zarazem główny cel projektu, jakim jest szeroko rozumiana pomoc w realizacji i promocji inicjatyw i dobrych praktyk w kwestii wdrażania czystego i zrównoważonego transportu miejskiego. Do tej pory przeprowadzono 4 etapy projektu CIVITAS, które realizowano w latach: 2002-2006 (CIVITAS I - 19 miast i 4 projekty pokazowe), 2005-2009 (CIVITAS II - 17 miast i 4 projekty pokazowe), 2008-2012 (CIVITAS Plus - 25 miast i 5 projektów pokazowych) oraz 2012-2016 (CIVITAS Plus II - 8 miast i 2 projekty pokazowe). Wśród Polskich miast w dotychcza-
} 
Według zaleceń Policy Advice Notes projektu CIVITAS podstawowymi etapami wdrożenia zrównoważonego planu mobilności miejskiej są:

1. Określenie celów, jakie ma przynieść wdrożenie planu mobilności (z uwzględnieniem specyfiki obszaru) oraz zdobycie partnerów wdrożenia i wyznaczenie jego lidera (menedżera ds. mobilności) koordynującego cały proces i gwarantującego jasny podział zadań

2. Wyznaczenie zakresu dzialania i nawiązanie współpracy z grupami adresatów (mogą nimi być: mieszkańcy miasta, pracownicy dużych firm/instytucji generujących duży ruch drogowy, dzieci i młodzież, a nawet przyjezdni i turyści).

3. Analiza stanu istniejącego, obejmująca przede wszystkim analizę zachowań transportowych i podziału modalnego (modal split), czyli procentowego udziału w transporcie na danym obszarze poszczególnych środków transportu (w podziale na główne grupy użytkowników: samochodu/taksówki, komunikacji publicznej, roweru i pieszych) oraz ocena dotychczasowych działań związanych z mobilnością w mieście i efektów kampanii promujących zrównoważone środki transportu miejskiego. To również etap gromadzenia doświadczeń z innych miast (w szczególności podobnych pod względem wielkości, położenia, specyfiki).

4. Konsultacje $\mathbf{z}$ adresatami projektu - czyli włączenie mieszkańców w dyskusję na temat mobilności, zapoczątkowane stworzeniem np. platformy e-learningowej czy miejskiego forum mobilności, którego uczestnicy stanowić będą najpierw partnerów w procesie doboru działań, a następnie naturalną grupę wsparcia zaplanowanych rozwiązań.

5. Sprecyzowanie dzialań koniecznych do wdrożenia w ramach planu mobilności, czyli wybór spośród propozycji tych, które najlepiej odpowiadają specyfice obszaru - często wykonywany w postaci publicznego głosowania lub wysłuchania.

6. Konsultacje zaproponowanych rozwiązań $z$ adresatami projektu, zapewniające maksymalną przejrzystość procesów planowania oraz demokratyczny i partycypacyjny sposób podejmowania decyzji.

7. Faza wdrażania wypracowanych dzialań i rozwiązań, obejmująca opracowanie planu wdrożenia poprzez wyszczególnienie działań, stworzenie harmonogramu i przydzielenie zadań poszczególnym partnerom. Na tym etapie często wymagane jest również systematyczne powielanie pewnych działań w czasie dla osiągnięcia efektu wzmocnienia.

8. Ewaluacja wdrożonych rozwiązań obejmująca pomiar bezpośrednich i pośrednich efektów wdrożenia oraz wyciągnięcie wniosków do wykorzystania w przyszłych działaniach. Co warte zaznaczenia - ujęcie efektów tzw. miękkich działań w sposób ilościowy może przysporzyć wiele trudności, dlatego ważne jest zdefiniowanie zestawu wskaźników, których wartości mierzone przed i po wdrożeniu działań zarządzania mobilnością pozwolą nam uzyskać wyniki w ujęciu porównawczym.

sowych edycjach Inicjatywy CIVITAS (i w różnych jej podprogramach) udział wzięły 4 miasta. Były to: Gdynia, Gdańsk, Szczecinek i Kraków. 
Dodatkowo elementami niezbędnymi, które często warunkują powodzenie wdrożenia, będą: przekonanie polityków i władz jednostki samorządu terytorialnego o sensie planowanego wdrożenia. W ocenie CIVITAS jest to szczególnie istotne w nowych państwach członkowskich Unii Europejskiej, gdzie „rosnąca liczba indywidualnych użytkowników samochodów wywiera nacisk na polityków, czego skutkiem jest niedocenianie przez nich skuteczności »miękkich« działań, takich jak marketing czy edukacja" (Policy Advice Notes 2008) w zakresie zrównoważonej mobilności miejskiej. Stąd tak istotne jest wsparcie wszystkich etapów wdrożenia działaniami marketingowymi i promocyjnymi, których zadaniem jest wzmacnianie pozytywnych efektów wprowadzanych zmian oraz informowanie głównych grup adresatów i beneficjentów zmian o ich celu. Są to działania bardzo ważne, bez których trudno oczekiwać sukcesu podejmowanego trudu wdrożenia SUMP.

Ostatnią kluczową kwestią jest często niedoceniane kryterium czasu. Czas trwania faz planowania i wdrożenia działań składających się na SUMP jest uzależniony od wielu czynników, takich jak np. rodzaj działań, wielkość populacji, do których dana kampania ma dotrzeć, rodzaju adresatów oraz wielkości funduszy, jakimi dysponuje podmiot wdrażający. Zwykłe kampanie promocyjne i edukacyjne zajmują najczęściej kilka miesięcy, ale już działania złożone i systemowe związane np. $\mathrm{z}$ budową kanału komunikacyjnego z grupą adresatów (portal mobilności, kursy ekojazdy) potrafią trwać i kilka lat. Należy również pamiętać, że dla uzyskania trwałości efektów działania te trzeba systematycznie powtarzać, gdyż efekt oddziaływania na zachowania ludzi narzędzi promocyjno-edukacyjnych wymaga znacznego czasu i zaangażowania (Policy Advice Notes 2008).

\section{Podsumowanie}

Problematyka mobilności w ujęciu logistyki miejskiej jest zagadnieniem bardzo złożonym. Wzrost jej znaczenia wiąże się z negatywnymi zjawiskami, jakie się z nią wiążą, z których na jakość życia ludzi najbardziej wpływają: kongestie, hałas oraz zanieczyszczenie środowiska. By niwelować te zjawiska, szczególnie na obszarach miejskich, stworzono koncepcję zarządzania mobilnością. Jest to jednak proces złożony, gdyż oddziałuje nie tylko na infrastrukturę, ład przestrzenny i sferę normatywną. Zarządzanie mobilnością przede wszystkim koncentruje się na wywieraniu wpływu na sferę psychologiczno-społeczną człowieka, jego opinie, poglądy i zachowania komunikacyjne, a jego głównym narzędziem są tzw. środki miękkie, czyli całe spektrum działań marketingowo-edukacyjno-informacyjnych. $\mathrm{W}$ toku rozwoju koncepcji zarządzania mobilnością wyodrębniono kilka typów instrumentów i cały wachlarz działań, mających na celu wywieranie wpływu na zachowania transportowe człowieka. Jednym z podstawowych lokalnych instrumentów administracyjno-prawnych, który stanowi przedmiot zainteresowania autora, jest zrównoważony plan mobilności miejskiej. Dokument ten jest zarazem swoistą bazą i na zasadzie synergii wspiera wdrażania instrumentów: planistycznych, inwestycyjnych, finansowych i edukacyjno-marketingowych. W wyniku wymiany dobrych praktyk i doświadczeń zdobytych w toku opracowywania planów mobilności miejskiej, w Unii Europejskiej udało się stworzyć katalog podstawowych 
etapów zarządzania jego wdrożeniem. Jest to między innymi zasługa powołanej, w ramach 5 Programu Ramowego Badań i Rozwoju, inicjatywy CIVITAS, której istotą jest łączenie miast Europy w swoiste partnerstwa i grupy wymiany informacji oraz dobrych praktyk, w oparciu o główne założenia uczestników prezentowane podczas dorocznych spotkań członków grup.

\section{Literatura}

1. Brzeziński A., Czym może być zrównoważony transport miejski, http://ucbs.uw.edu.pl/wpcontent/uploads/Brzezi\%C5\%84ski.Zr\%C3\%B3wnowa\%C5\%BC.transport.pdf, s. 1-9 (dostęp: 20.01.2016).

2. Chamier-Gliszczyński N., Krzyżyński T. (2011), Zrównoważona mobilność w miastach, „Logistyka” nr 3, s. 321-328.

3. Ciastoń-Ciulkin A., Puławska S. (2014), Badania zachowań transportowych $w$ miastach z wykorzystaniem Internetu, „Logistyka” nr 6, s. 2750-2758.

4. Engelskirchen M. (2011), Sustainable Transport. A Sourcebook for Policy-Makers in Developing Cities, GTZ.

5. Hebel K. (2014), Mobilność mieszkańców miast w XXI wieku, „Logistyka” nr 2, s. 88-96.

6. Hebel K. (2013), Zachowania transportowe mieszkańców w ksztaltowaniu transportu miejskiego, Fundacja Rozwoju Uniwersytetu Gdańskiego, Gdańsk 2013.

7. http://docplayer.pl/1887295-Ministerstwo-infrastruktury-polityka-transportowa-panstwa-nalata-2006- 2025.html (dostęp: 20.02.2016).

8. http://ec.europa.eu/eurostat/cache/RSI/\#?vis=typologies.urb_typology (dostęp: 19.02.2016).

9. http://ec.europa.eu/eurostat/statistics-explained/index.php/File:Annual_net_earnings, 2014 (EUR) YB15.png (dostęp: 19.02.2016).

10. http://edroga.pl/inzynieria-ruchu/katowice-strefa-tempo-30-juz-obowiazuje-170811883 (dostęp: 19.02.2016).

11. http://sjp.pwn.pl/slowniki/mobilno\%C5\%9B\%C4\%87.html (dostęp: 19.02.2016).

12. http://stat.gov.pl/cps/rde/xbcr/gus/lu_nps2011_wyniki_nsp2011_22032012.pdf, s. 6 (dostęp: 19.02.2016).

13. http://uniaeuropejska.org/eurostat-41-proc-europejczykow-mieszka-w-miastach/ (dostęp: 19.02.2016).

14. http://www.gdansk.pl/urzad/mobile,512,11727.html (dostęp: 19.02.2016).

15. http://www.metropoliagdansk.pl/upload/files/2_Raport\%20szczeg\%C3\%B3\%C5\%82owy\% 20badania\%20i\%20pomiary\%20XII\%202014.pdf (dostęp: 19.02.2016).

16. http://www.tomtom.com/pl_pl/trafficindex/\#/list (dostęp: 19.02.2016).

17. http://www.vtpi.org/tdm/tdm67.htm (dostęp: 19.02.2016).

18. Litman T. (2002), Mobility Management. Sustainable Transport. A Sourcebook for Policy-Makers in Developing Cities, GTZ.

19. Litman T., Potential Transportation Demand Management Strategies, Victoria Transport Institute, Online TDM Encyclopedia, www.vtpi.org/tdm/tdm67.htm

20. Low N., Gleeson B., Green R., Radovic D. (2005), The Green City. Sustainable Homes, Sustainable Suburbs, Routledge, Abingdon Oxfordshire.

21. Niewitała D., Ochyra M. (2008), Innowacyjne działania w zakresie popularyzowania i promowania idei zrównoważonej mobilności, „Transport Miejski i Regionalny”, nr 7-8, s. 12-16.

22. Nosal K. (2011), Review of Methodologies for Evaluation of Effectiveness of Mobility Management Soft Instruments, [w:] Janecki R., Sierpiński G. (red.), New Mobility Culture. Contemporary Transportation Systems. Selected Theoretical and Practical Problems, s. 83-91, Wydawnictwo Politechniki Śląskiej, Gliwice. 
23. Nosal K. (2014), Skuteczność kampanii „,Tydzień zrównoważonej mobilności” oraz „Dzień bez samochodu” promujących proekologiczne środki transportu, „Logistyka” nr 3, s. 4687-4696.

24. Nosal K., Starowicz W. (2010), Wybrane zagadnienia zarządzania mobilnościa, http://www.ekoszkola.pl/media/filemanager/publikacje/mobilnosc/zarzadzanie_mobilnoscia. pdf (dostęp: 19.02.2016).

25. Nosal K. (2009), Wpływ planów mobilności na zmianę zachowań komunikacyjnych, [w:] Modelowanie podróży i prognozowanie ruchu, Zeszyty Naukowo-Techniczne Stowarzyszenia Inżynierów i Techników Komunikacji w Krakowie, seria: Materiały Konferencyjne, nr 90, z. 148, SITK, Kraków, s. 177-196.

26. Nowakowska-Grunt J., Chłąd M. (2015), Mobilność jako element zarzadzania miastem, „Zeszyty Naukowe Politechniki Częstochowskiej. Zarządzanie” 2015, nr 20.

27. Opracowanie Dyrekcji Generalnej ds. Polityki Wewnętrznej Komisji Europejskiej, Plan zrównoważonego transportu miejskiego, 2010, s. 15, http://www.europarl.europa.eu/Reg Data/etudes/note/join/2010/431594/IPOL-TRAN_NT\%282010\%29431594_PL.pdf (dostęp: 29.06.2015).

28. Pifczyk Sz. (2016), Turniej miast. Zobacz, co robia miasta w Polsce, żeby wyprzedzić rywa$l i$, http://biqdata.pl/ilu-polakow-mieszka-w-miastach (dostęp: 19.02.2016).

29. Policy Advice Notes (2008), Promowanie nowej kultury mobilności w miastach, CIVITAS, http://www.civitas.eu/sites/default/files/civitas_ii_policy_advice_notes_08_promotion_and_ education_pl.pdf(dostęp: 19.02.2016).

30. Rudnicki A., Starowicz W. (2007), Transport miejski, [w:] Liberadzki B., Mindura L. (red.), Uwarunkowania rozwoju systemu transportowego Polski, s. 396-421, Wydawnictwo Instytut Technologii Eksploatacji - PIB, Warszawa-Radom.

31. Rudnicki A. (2010), Zrównoważona mobilność a rozwój przestrzenny miasta, „Czasopismo Techniczne. Architektura”, R. 107, z. 1-A, Wydawnictwo Politechniki Krakowskiej, s. 57-74.

32. Suchorzewski W. (2009), Opłaty za wjazd do obszarów śródmiejskich - sukcesy i porażki, [w:] Kacznarek M., Krycha A. (red.), Skuteczne zmniejszenie zattoczenia miast, s. 195-206, Poznań-Rosnówko.

33. Szołtysek J. (2011), Kreowanie mobilności mieszkańców miast, Wolters Kluwer, Warszawa.

34. Urry J. (2009), Socjologia mobilności, Wydawnictwo Naukowe PWN, Warszawa.

35. Załącznik do Uchwały nr 238.XX.2015 Rady Miasta Częstochowy z dnia 30 grudnia 2015 r. w sprawie Planu zrównoważonego rozwoju publicznego transportu zbiorowego dla Miasta Częstochowy, Dziennik Urzędu Wojewódzkiego Województwa Śląskiego z dnia 19 stycznia 2016, poz. 481.

36. Załącznik do uchwały Rady Miasta Wrocławia z dnia 19 września 2013 r. nr XLVIII/1169/13.

\title{
URBAN MOBILITY MANAGEMENT - INSTRUMENTS AND BASIC STEPS FOR IMPLEMENTATION OF SUSTAINABLE URBAN MOBILITY PLANS (SUMP)
}

\begin{abstract}
The article is devoted to selected issues related to the problems of urban mobility. Starting from the problems that are associated with increased mobility will be described goals and essence of the mobility management development concept. The main field of interest will be urban area due to the concentration of negative phenomena associated with increased mobility. In addition, based on the research literature will be presented a catalog of the most important instruments and management measures for urban mobility.
\end{abstract}

Keywords: urban mobility, comunication/transportation behavior, Sustainable Urban Mobility Plan, SUMP, sustainable urban management 